\title{
FACTORS AFFECTING INTENTION TO USE FOOD ORDER-DELIVERY FEATURE OF RIDE-HAILING APPLICATIONS: THE UTAUT APPROACH
}

\author{
Ade Permata Surya* \\ Faculty of Economics and Business, Universitas Diponegoro and \\ Faculty of Economics and Business, Universitas Mercu Buana \\ I Made Sukresna \\ Faculty of Economics and Business, Universitas Diponegoro \\ Aris Mardiyono \\ Faculty of Economics and Business, Universitas Diponegoro
}

\begin{abstract}
Since ride-hailing platforms in Indonesia provide food order-delivery feature, there has been a change in public spending behavior from conventional to electronic, even on the most basic element, i.e., food. The purpose of this study is to identify critical factors affecting consumers' adoption of ride-hailing applications to buy food using the Unified Theory of Acceptance and Use of Technology (UTAUT) approach. This study uses a cross-sectional design with a non-probability sampling method. Data was collected from selfadministered questionnaire, resulting a total sample of 315 respondents across Indonesia. The respondents are GrabFood and GoFood consumers and the food order-delivery feature of Grab and Gojek (the ridehailing applications). The study employs PLS-SEM technique to analyze the relationships among variables. The findings show performance expectancy, social influence, and facilitating conditions positively influence behavioral intention to use food order-delivery features in ride-hailing applications. On the other hand, effort expectancy does not influence behavioral intention. The results corroborate the role of food-order feature of ride-hailing applications in the change of Indonesian consumer behavior. Referring to the study results, theoretical contributions and practical implications are provided.
\end{abstract}

Keywords: Behavioral intention; UTAUT; Ride-hailing applications; Food order-delivery feature

Received: 9 November 2019

Accepted: 27 September 2021

https://doi.org/10.33736/ijbs.4306.2021

\section{INTRODUCTION}

Along with the increasing use of the internet and the proliferation of smartphones, ride-hailing mobile applications have experienced rapid growth in recent years (He et al., 2018; Vivoda et al, 2018). Ride-hailing applications, also known as e-Hailing apps, taxi-hailing app, car-hailing

*Corresponding author: Universitas Diponegoro, Jl. Prof. Soedarto, SH, Tembalang, Semarang, Indonesia; and Universitas Mercu Buana, J1. Meruya Selatan No.1, Jakarta, Indonesia; Mobile +6285711967737; Email: adepermatasurya@students.undip.ac.id; 
commerce, ride-sourcing, ride-sharing, car-sharing, vehicle-for-hire, on-demand ride services, or online transportation (Cheng et al., 2018; Contreras \& Paz, 2018; Fleury et al., 2017; He et al., 2018; Vivoda et al, 2018), are modern mobile service applications processing requests for transportation services through internet, conducting geo-location using information systems and telephone calls, and tracking the service route and the payment (Joia \& Altieri, 2018). According to Contreras and Paz (2018), ride-hailing is the act of calling a drive from a private passenger vehicle through the web application portal of a smartphone in which the system is regulated and operated by ride-hailing companies (RHCs).

According to Indonesian Digital Report (2020), Indonesia has a total number of active internet users reaching 175.4 million and a total number of mobile connections reaching 338.2 million. It shows a great potential for ride-hailing companies (RHCs) to develop their markets in Indonesia. As recorded, there are at least two of the largest RHCs in Indonesia, namely Gojek and Grab. In addition to providing transportation service facilities with a variety of vehicle options such as car, taxi, and motorbike taxi, they provide food order-delivery feature using motorbike taxi. In Grab, the feature is called GrabFood (grab.com), while in Gojek it is called GoFood (gojek.com).

Generally, steps in food order-delivery feature of ride-hailing applications are as follow: (1) customer chooses restaurant(s) in the applications' list, (2) customer reads food menu and places an order, (3) customer types shipping address, then the application will calculate the rate according to the distance of the shipment and allocate the closest driver to the restaurant, (4) driver buys and delivers the orders, (5) the customer tracks the location of the driver, order progress, and estimated time of arrival of the orders. This platform may deliver benefits to participating parties. Consumers can choose types of food and restaurants quickly and easily by comparing the available alternatives. The participating-food-business owners also experience benefits as they may reduce burdens in non-main activities (Pigatto et al., 2017).

The emergence of food order-delivery feature on ride-hailing applications in Indonesia may correlate to a change in public spending behavior from conventional to electronic even on the most basic element, i.e., food. People, nowadays, like to order food through online applications rather than buying directly at retailers (offline) or cooking food by themselves (Valenta, 2019). The growth of purchasing power of $\mathrm{C}$ socio-economic class (households with $0.87-1.18$ times the average estimated income per capita) and D socio-economic class (households with under average estimated income per capita - around 0.75 times the average) (Nielsen Admosphere, 2019) correlates to the demand for fast food due to the lack of consumers' time, extra convenience, advancement in telecommunication infrastructure and the affordable smartphones, etc. Those factors contribute to the immediate and and exponential growth of the ride-hailing business model (Pigatto et al., 2017). The possibility of change in consumer behavior is corroborated by 2018 household consumption data from the Indonesian Central Statistics Agency. By the end of 2018, total household consumption grew 5.08 percent, higher than the same period in 2017. This growth was in line with the growth of the transportation and communication sector, which grew 6.14 percent in 2018 or increased 5.04 percent from the same period in 2017. Nonetheless, throughout 2018, the actual level of consumption of food and beverages declined to $4.81 \%$ from $5.36 \%$ in 2017 . Conversely, the transportation-communication component grew from $5.04 \%$ to $6.14 \%$, and restaurants grew from $5.31 \%$ to $5.85 \%$. This indicates a decrease in offline consumption as people began to reduce groceries purchase and switch to prepared foods. 
Moreover, GoFood also announces an increasing number of orders throughout 2018. Over the previous year, GoFood has succeeded in delivering more than 500 million orders of food and beverages, or $16,676,241$ food servings, with a total delivery distance of $624,971,059 \mathrm{~km}$. The total transaction (Gross Transaction value/GTV) of GoFood reached US\$ 2 billion in 2018. The number of GrabFood food deliveries also increased 6 times since the first time the feature had been launched. In addition, GoFood already has 400,000 registered merchant partners and has reached up to 204 cities in Indonesia. Meanwhile, GrabFood has also collaborated with hundreds of thousands of merchants and is present in 178 cities in Indonesia. The merchants include national to international franchise outlets, restaurants, and even culinary SMEs. Despite such expansion, the ride-hailing applications remain developing various new features, yet it seems not all old users will immediately want to use the new features. Based on this practical problem, it is necessary to know what factors influence consumers in adopting the ride-hailing app in general and their food delivery features in specific. Consequently, companies could effectively implement strategies to retain old users and attracting new users.

On the theoretical ground, previous research about ride-hailing applications show a greater concern for the applications' service quality (Cheng et al., 2018); optimal design and programming algorithm (He et al., 2018; He \& Shen, 2015; Yu et al., 2019); its effect on the taxicab industry (Contreras \& Paz, 2018); and ride-hailing applications' knowledge, use, reliance, and future expectations among consumers (Vivoda et al., 2018). However, previous studies did not focus on aspects related to 'consumer's acceptance and intention to use the applications. Only few works concern with this topic (e.g., Fleury et al., 2017; Joia \& Altieri, 2018), but their studies focus on ride-sharing features instead of food order-delivery feature. Most of the studies used Theory of Reasoned Action (TRA) and Theory of Planned Behavior (TPB) (Joia \& Altieri, 2018) and Unified Theory of Acceptance and Use of Technology (UTAUT) in the setting of a developed country (Lee et al., 2019). Only few research focuses on 'consumer's intention of adopting food order-delivery feature provided by the ride-hailing applications using the UTAUT approaches in developing countries (e.g., Alalwan, 2020; Karulkar et al., 2019). Hence, this study tries to fill the research gaps and specifically tries to answer two research questions: (1) What factors influence the intention to use food orderdelivery feature under UTAUT lens?; and (2) Are there any connections between the UTAUT factors with the shift in consumer behavior in Indonesia from offline into online purchase? By answering the questions, this study aims to identify the critical factors affecting consumers adoption of ride-hailing applications to buy food through online application based on the UTAUT - Unified Theory of Acceptance and Use of Technology (Venkatesh et al., 2003) and their possible correlations with the change of consumer behavior in Indonesia as a developing country.

\section{LITERATURE REVIEW}

\subsection{Previous Studies}

Prior literature has shown there were 12 empirical studies investigating issues of both RideHailing Apps (RHA) and Food-Delivery Apps (FDA) adoption factors (see Table 1). Eight 
studies discuss FDA adoption factors, and 4 studies discuss RHA adoption factors. These studies were conducted in various countries, either in developed countries or developing countries.

Some of them use single theory in building models (Alalwan, 2020; Karulkar et al., 2019; Lee et al., 2019; Wang et al., 2020), and some use a combination of various theories (Acheampong et al., 2020; Joia \& Altieri, 2018; Lu \& Wang, 2020; Ray et al., 2019; Zhao \& Bacao, 2020). For instance, Belanche et al. (2020) use an extended of TPB in knowing the factors of FDA adoption in US, where they add the security and app lifestyle compatibility variables to the model. They also added a consequence variable of WOM Intention. The results reveal attitude toward the behavior, subjective norms, and app lifestyle compatibility influence customer use of food delivery apps in Spain. Whereas, Wang et al. (2020) deploys Technology Acceptance Model (TAM) to build and modify a model for predicting the adoption factors of ride-hailing app in China. Their results indicate personal innovativeness, environmental awareness, and perceived usefulness are positively associated with 'consumers' intention to use RHA.

In addition, previous studies extend UTAUT model or UTAUT2 (Alalwan, 2020; Lee et al., 2019; Karulkar et al., 2019). Alalwan (2020) extends UTAUT and examines the determinant factors in adopting a mobile food ordering app. The results show that online review, online rating, online tracking, performance expectancy, hedonic motivation, and price value significantly influence continued intention to reuse FDA. Lee et al. (2019) develop a model on predicting factors for FDA adoption and confirm the importance of information quality, performance expectancy, habit, and social influence as factors in inducing 'users' continuous use intention for food delivery apps in Korea. Karulkar et al. (2019) develop a model to predict factors affecting intention to use online food delivery services in India and reveal performance expectancy, including effort expectancy, social influence, and facilitating conditions deliver significant influences on intention to use online food delivery services.

Furthermore, the rest of the studies combine several theories to build their models. Zhao and Bacao (2020) use the UTAUT, the Expectancy Confirmation Model (ECM), and Perceived Tasktechnology Fit (TTF) theories to investigate the relationship of confirmation, satisfaction, performance expectancy, effort expectancy, social influence, trust, and continuance intention. They found delivery satisfaction shows the greatest impact on users' intention to use FDAs during the COVID-19 pandemic period. Lu and Wang (2020) integrate TAM, TPB, DOI (Diffusion of Innovation) and UTAUT2 to predict Chinese users' adoption of ride-hailing app and find perceived value positively correlates with travelers' behavioral intention to use ridehailing service. Acheampong et al. (2020) combine TAM, TPB, and TDT (Technology Diffusion Theory) theories in developing their model. Joia and Altieri (2018) integrate Information Systems Acceptance, TPB, TAM, and DOI to predict E-Hailing Apps factors adoption. They found perceived utility, compatibility, relative advantage, and trust drive user satisfaction with RHA and subjective norms have significant impact on the continued use intention of RHA.

Table 1: Selected Studies on Food-Delivery and Ride-Hailing Applications

\begin{tabular}{lllll}
\hline \multicolumn{1}{c}{ Authors } & \multicolumn{1}{c}{ Constructs } & \multicolumn{1}{c}{ Theory } & \multicolumn{1}{c}{ Sample } & \multicolumn{1}{c}{ Key Findings } \\
\hline Acheampong et & Perceived Benefits, & TAM, & 1188 RHA & Ride-hailing is \\
al. (2020) & Environmental Attitude and & TPB, & users in & preferred for full \\
& Values, Attitude toward Car- & and & Ghana & door-to-door
\end{tabular}




\begin{tabular}{|c|c|c|c|c|}
\hline Authors & Constructs & Theory & Sample & "Key Findings \\
\hline & $\begin{array}{l}\text { Ownership and Use, Perceived } \\
\text { Ease of Use, Perceived Control; } \\
\text { ICT Use in Travel, Technology } \\
\text { Attitude, Openness to Innovation, } \\
\text { Perceived Innovativeness, } \\
\text { Perceived Safety Risk }\end{array}$ & TDT & & $\begin{array}{l}\text { journeys, instead of } \\
\text { as complementing } \\
\text { modes }\end{array}$ \\
\hline Alalwan (2020) & $\begin{array}{l}\text { Performance Expectancy, Effort } \\
\text { Expectancy, Social Influence, } \\
\text { Facilitating Condition, Hedonic } \\
\text { Motivation, Price Value, Habit, } \\
\text { Online Review, Online Rating, } \\
\text { Online Tracking, Continued } \\
\text { Intention }\end{array}$ & $\begin{array}{l}\text { UTAUT } \\
2\end{array}$ & $\begin{array}{l}500 \text { FDA } \\
\text { users in } \\
\text { Jordan }\end{array}$ & $\begin{array}{l}\text { Online review, } \\
\text { online rating, online } \\
\text { tracking, and } \\
\text { UTAUT2 factors } \\
\text { influence e- } \\
\text { satisfaction and } \\
\text { continued intention } \\
\text { to reuse FDA }\end{array}$ \\
\hline $\begin{array}{l}\text { Belanche et al. } \\
\text { (2020) }\end{array}$ & $\begin{array}{l}\text { Attitude, Subjective Norms, } \\
\text { Perceived Control, Security, App } \\
\text { Lifestyle Compatibility, Intention } \\
\text { to Use, WOM Intention }\end{array}$ & TPB & $\begin{array}{l}248 \text { FDA } \\
\text { users in } \\
\text { Spain }\end{array}$ & $\begin{array}{l}\text { Security influences } \\
\text { intention to spread } \\
\text { WOM, whilst } \\
\text { lifestyle } \\
\text { compatibility affects } \\
\text { intention to use the } \\
\text { FDA }\end{array}$ \\
\hline $\begin{array}{l}\text { Joia and Altieri } \\
\text { (2018) }\end{array}$ & $\begin{array}{l}\text { Subjective Norms, Perceived } \\
\text { Usefulness, Perceived Ease of } \\
\text { Use, Complexity, Compatibility, } \\
\text { Relative Advantage, Trust, User } \\
\text { Satisfaction, Continued Use } \\
\text { Intention }\end{array}$ & $\begin{array}{l}\text { Informat } \\
\text { ion } \\
\text { Systems } \\
\text { Accepta } \\
\text { nce, } \\
\text { TPB, } \\
\text { TAM, } \\
\text { and DOI }\end{array}$ & $\begin{array}{l}330 \text { RHA } \\
\text { users }\end{array}$ & $\begin{array}{l}\text { Perceived utility, } \\
\text { compatibility, } \\
\text { relative advantage, } \\
\text { and trust influence } \\
\text { user satisfaction, } \\
\text { whilst subjective } \\
\text { norms increase the } \\
\text { continued use } \\
\text { intention of RHA }\end{array}$ \\
\hline $\begin{array}{l}\text { Karulkar et al. } \\
\text { (2019) }\end{array}$ & $\begin{array}{l}\text { Performance Expectancy, Effort } \\
\text { Expectancy, Social Influence, } \\
\text { Facilitating Condition, Perceived } \\
\text { Control, Hedonic Motivation }\end{array}$ & $\begin{array}{l}\text { UTAUT } \\
2\end{array}$ & $\begin{array}{l}253 \text { FDA } \\
\text { users in } \\
\text { India }\end{array}$ & $\begin{array}{l}\text { This study validates } \\
\text { the application of } \\
\text { modified UTAUT } \\
\text { model in FDA } \\
\text { setting }\end{array}$ \\
\hline Lee et al. (2019) & $\begin{array}{l}\text { Information Quality, Performance } \\
\text { Expectancy, Effort Expectancy, } \\
\text { Social Influence, Facilitating } \\
\text { Condition, Hedonic Motivation, } \\
\text { Price Value, Habit }\end{array}$ & $\begin{array}{l}\text { UTAUT } \\
2\end{array}$ & $\begin{array}{l}340 \text { FDA } \\
\text { users in } \\
\text { Korea }\end{array}$ & $\begin{array}{l}\text { This study validates } \\
\text { the importance of } \\
\text { information quality, } \\
\text { performance } \\
\text { expectancy, habit, } \\
\text { and social influence } \\
\text { in stimulating users' } \\
\text { continuous use } \\
\text { intention for FDA }\end{array}$ \\
\hline $\begin{array}{l}\text { Lu and Wang } \\
(2020)\end{array}$ & $\begin{array}{l}\text { Perceived Usefulness, Perceived } \\
\text { Enjoyment, Behavioral Intention, } \\
\text { Subjective Norm, Social Image, } \\
\text { Perceived Value, Perceived } \\
\text { Policy Support, Perceived Fee, } \\
\text { Performance Risk }\end{array}$ & $\begin{array}{l}\text { TAM, } \\
\text { TPB, } \\
\text { DOI, } \\
\text { and } \\
\text { UTAUT } \\
2\end{array}$ & $\begin{array}{l}414 \text { RHA } \\
\text { users in } \\
\text { China }\end{array}$ & $\begin{array}{l}\text { Perceived value } \\
\text { positively } \\
\text { influences } \\
\text { behavioral } \\
\text { intention, whereas } \\
\text { perceived sacrifice } \\
\text { negatively affects }\end{array}$ \\
\hline
\end{tabular}



Applications: The Utaut Approach

\begin{tabular}{|c|c|c|c|c|}
\hline Authors & Constructs & Theory & Sample & "Key Findings \\
\hline Ray et al. (2019) & $\begin{array}{l}\text { Convenience, Societal Pressure, } \\
\text { Customer Experience, Delivery } \\
\text { Experience, Search of } \\
\text { Restaurants, Quality Control, } \\
\text { Listing, Ease-of-Use }\end{array}$ & $\begin{array}{l}\text { Uses } \\
\text { and } \\
\text { Gratific } \\
\text { ations } \\
\text { (U\&G) } \\
\text { Theory }\end{array}$ & $\begin{array}{l}\text { Interviews } \\
\text { with } 125 \\
\text { FDA users } \\
\text { and survey } \\
\text { with } 395 \\
\text { FDA users }\end{array}$ & $\begin{array}{l}\text { perceived value } \\
\text { Customer } \\
\text { experience, search } \\
\text { of restaurants, ease- } \\
\text { of-use and listing } \\
\text { significantly affect } \\
\text { intentions to use } \\
\text { FDA }\end{array}$ \\
\hline $\begin{array}{l}\text { Wang et al. } \\
(2020)\end{array}$ & $\begin{array}{l}\text { Personal Innovativeness, } \\
\text { Perceived Ease of Use, Perceived } \\
\text { Usefulness, Perceived Risk, } \\
\text { Environmental Awareness, } \\
\text { Behavioral Intention }\end{array}$ & TAM2 & $\begin{array}{l}426 \text { RHA } \\
\text { users in } \\
\text { China }\end{array}$ & $\begin{array}{l}\text { Perceived ease of } \\
\text { use does not } \\
\text { influence intention } \\
\text { to use RHA }\end{array}$ \\
\hline $\begin{array}{l}\text { Zhao and Bacao } \\
(2020)\end{array}$ & $\begin{array}{l}\text { Confirmation, Satisfaction, } \\
\text { Performance Expectancy, Effort } \\
\text { Expectancy, Social Influence, } \\
\text { Trust, Continuance Intention }\end{array}$ & $\begin{array}{l}\text { UTAUT } \\
\text { ECM, } \\
\text { and TTF }\end{array}$ & $\begin{array}{l}532 \text { FDA } \\
\text { users in } \\
\text { China }\end{array}$ & $\begin{array}{l}\text { Satisfaction is the } \\
\text { most significant } \\
\text { factor in influencing } \\
\text { continuous intention } \\
\text { to use FDA }\end{array}$ \\
\hline
\end{tabular}

\subsection{Unified Theory of Acceptance and Use of Technology (UTAUT)}

A number of models tries to predict factors associated with the acceptance of technologies (Rondan-Cataluña et al., 2015). Venkatesh et al. (2003) develop an integrated model uniting alternative views about user acceptance and innovation called The Unified Theory of Acceptance and Use of Technology (UTAUT) to align the literature related to the acceptance of new technology. Four main constructs (performance expectancy, effort expectancy, social influence, and facilitating conditions) are suggested as determinants of behavioral intention and ultimately behavior and several factors (gender, age, experience, and voluntariness of use) are posited to moderate the constructs. The combination of Theory of Reasoned Action (TRA), the Technology Acceptance Model (TAM), the Motivational Model, the Theory of Planned Behavior (TPB), a combined TBP/TAM, the Model of PC Utilization, Innovation Diffusion Theory (IDT), and Social Cognitive Theory (SCT) has developed the theory of UTAUT. An extant number of former researches on technology or innovation adoption and diffusion, within a range of disciplines including information systems, marketing, social psychology, and management, have widely and successfully utilized these contributing theories and models. Venkatesh et al. (2003) conduct a six-month study and show the eight contributing models explained $17 \%-53 \%$ of variance in user intentions to adopt IT. Moreover, this UTAUT model is reported to perform better than the eight individual models with an adjusted $\mathrm{R}^{2}$ of $69 \%$ (Venkatesh et al., 2003). For example, UTAUT is better than TAM since TAM inadequately explains the interplay between various external factors and the TAM variables (Agarwal \& Karahanna, 2000; Lee et al., 2019) and generally ill-explain work-technology environments (Morosan \& DeFranco, 2016). As such, recently UTAUT is probably the most valid and recent technology adoption model used in assessing intention to use technology (Shiferaw \& Mehari, 2019).

The UTAUT model explains behavioral intention to use technology in various fields, including in the food delivery applications. This model is deployed in current studies such as in Alalwan (2020), Karulkar et al. (2019), and Lee et al. (2019). Alalwan (2020) proposes an integrated 
model based on the extended UTAUT and the features of Mobile Food Ordering Apps (MFOAs), like online review, online rating, and online tracking. They found performance expectancy, online review, online rating, online tracking, hedonic motivation, and price value significantly influence e-satisfaction and continued intention to reuse MFOAs in Jordan. In addition, Karulkar et al. (2019) examine the adoption of Online Food Delivery services by adding perceived control and hedonic motivation in UTAUT model and found only performance expectancy, effort expectancy, social influence and facilitating conditions deliver significant influences on intention to use OFD services in India. Furthermore, Lee et al. (2019) analyze an extended UTAUT model that augments information quality to identify the determinants of continuous use intention for food delivery software applications in Korea, involving 340 respondents. The results show that habit displays the strongest influence on continuous use intention, followed by performance expectancy and social influence.

Based on the wide application of UTAUT, our study grounds on Venkatesh et al. (2003)' work to identify four variables within UTAUT model affecting consumers' adoption of food delivery feature in ride-hailing applications, namely performance expectancy, effort expectancy, social influence, and facilitating condition.

\section{HYPOTHESIS DEVELOPMENT}

\subsection{Performance Expectancy and Behavioral Intention}

Performance expectancy refers to the extent to which a person belief that using a system will support him/her to gain advantage(s) in job performance (Venkatesh et al., 2003). Five constructs from the different models related to performance expectancy are perceived usefulness (TAM/TAM2 and C-TAM-TPB), extrinsic motivation (MM), job-fit (MPCU), relative advantage (IDT), and outcome expectations (SCT) (Venkatesh et al., 2003). Empirical studies show there is an influence of performance expectancy on behavioral intention (Farooq et al., 2017; Mehta et al., 2019; Naranjo-Zolotov et al., 2019; Suki \& Suki, 2017). Farooq et al. (2017) found performance expectancy in the domain of information technology (IT) have significant positive influence on acceptance and use of lecture capture system (LCS) in executive business students. In addition, Mehta et al. (2019) suggested that the adoption of e-learning shows a significant performance expectancy effect on behavioral intention to adopt it. In the field of education, Suki and Suki (2017) also found performance expectancy delivers the most prevailing determinant of 'students' behavioral intention to use animation and storytelling, and hence the students become more creative in their communication of stories, ideas, and concepts with peer groups. In a same vein, within e-participation research, Naranjo-Zolotov et al. (2019) found performance expectancy is the strongest predictors of intention to use e-participation. We, therefore, hypothesize:

\section{H1: Performance expectancy positively affects 'user's intention to use ride-hailing} applications' feature for buying food

\subsection{Effort Expectancy and Behavioral Intention}


Effort expectancy is the level of convenience associated with the system utilization (Venkatesh et al., 2003). Three constructs from the existing models form the concept of effort expectancy, namely: perceived ease of use (TAM/TAM2), complexity (MPCU), and ease of use (IDT) (Venkatesh et al., 2003). Prior studies have shown that effort expectancy influences intention to use technology (Isaac et al., 2019; Rana et al., 2016; Sumak \& Sorgo, 2016; Wong et al., 2013). Isaac et al. (2019) found that effort expectancy positively influences internet use within organizations in Yemen. Similarly, Rana et al. (2016) found that effort expectancy delivers significant effect on the adoption of online-public-grievance redressal system in India. Wong et al. (2013) also found that effort expectancy influences early-childhood-student 'teachers' acceptance and use of interactive whiteboard. The findings indicated effort expectancy may determine 'individual's attitude in adopting or using technology. Based on the findings, the following hypothesis can be formulated:

\section{H2: Effort expectancy positively influences 'user's intention to use ride-hailing applications' feature for buying food}

\subsection{Social Influence and Behavioral Intention}

Social influence refers to the level to which a person apprehends that his/her surroundings believe he/she must use a new system (Venkatesh et al., 2003). Social influence in its role as an antecedent of behavioral intention is described as subjective norm in TRA, TAM2, TPB/DTPB and C-TAM-TPB, social factors in MPCU, and image in IDT. Thompson et al. (1991) applied the expression of social norms in interpreting their construct and recognized its similarity to subjective norm within TRA. Whilst they have various names, each construct consists of explicit or implicit notion that the individual's behavior is affected by how they believe others will view them as a result of having used a technology (Venkatesh et al., 2003). Empirical studies show the influence of social influence on behavioral intentions (Chua et al., 2018; Howard et al., 2017; Kurfal1 et al., 2017; Lwoga \& Komba, 2015; Macedo, 2017). Here, Chua et al. (2018) found that social influence determine behavioral intention towards social networking applications. Macedo (2017) revealed social influence correlates with behavioral intention to use information and communication technology (ICTs) by older adults. The impact of social influence on behavioral intention was also found in research on adoption of e-government services in Turkey (Kurfalı et al., 2017); adoption of building information modeling (BIM) (Howard et al., 2017); continued usage intentions of web-based learning management system in Tanzania (Lwoga \& Komba, 2015). Based on the literature, the following hypothesis is proposed:

\section{H3: Social influence positively influences 'user's intention to use ride-hailing applications' feature for buying food}

\subsection{Facilitating Condition and Behavioral Intention}

Facilitating condition definition refers to the level of a person believes that an organizational and technical infrastructure prevails to endorse the system utilization (Venkatesh et al., 2003). This definition covers ideas embodied by three different constructs, namely: perceived behavioral control (TPB/DTPB, C-TAM-TPB), facilitating conditions (MPCU), and compatibility (IDT). Each construct is functionalized to incorporate the technological and/or organizational environment aspects that are planned to remove barriers to utilization. Taylor and Todd (1995) 
recognized the theoretical convergence by modeling facilitating conditions as a core component of perceived behavioral control in TPB/DTPB. The suitability construct from IDT affiliates items that tap the fit between the individual's work manner and the use of the system in the organization (Venkatesh et al., 2003). Former studies have shown facilitating condition positive influences behavioral intention (Howard et al., 2017; Jewer, 2018; Kurfall et al., 2017; ReyesMercado, 2018; Zhou et al., 2020). Here, Zhou et al. (2020) states that facilitating condition is positive determinant to adopt self-service parcel services for last-mile delivery. Reyes-Mercado (2018) found non-adopters may follow a number of paths to intention to use fitness wearables through facilitating conditions. In addition, Jewer (2018) revealed that facilitating conditions affect patients' behavioral attention to accept and use Emergency Department (ED) wait-times website. The impact of facilitating conditions on behavioral intention was also found in research on adoption of e-government services in Turkey (Kurfalı et al., 2017) and adoption of building information modeling (BIM) (Howard et al., 2017). Consistent with the existing literature, it is expected that higher facilitating condition would lead to higher levels of intention to use ridehailing applications' feature for buying food and as such this leads to the following hypothesis:

\section{H4: Facilitating condition positively influences 'user's intention to use ride-hailing applications' feature for buying food}

\subsection{Research Framework}

Based on the hypothesis development, Figure 1 displays the research framework of this study.

Figure 1: Research Framework

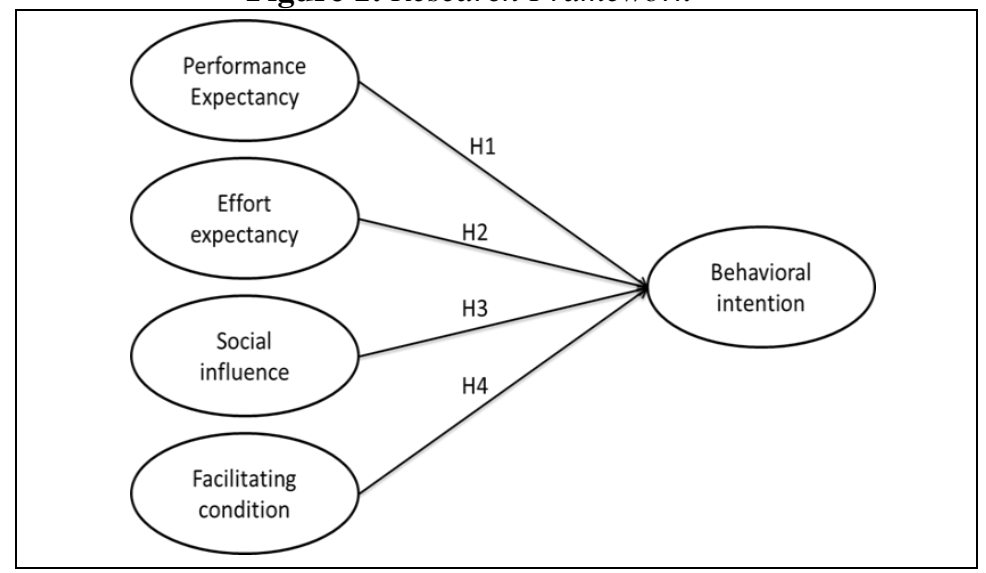

\section{METHODOLOGY}

This research uses a quantitative approach, cross-sectional, and deploys survey method. The population is the users of food order and delivery feature available on ride-hailing applications (users of GrabFood feature from Grab application or GoFood from Gojek application) in Indonesia. In total, the research samples obtained are 315 respondents, determined using non- 
probability sampling technique. In order to test the conceptual model, a questionnaire was developed using constructs and items from previous literature. Measurement items for performance expectancy (PE), effort expectancy (EE), social influence (SI) and facilitating condition (FC) are adapted from (Venkatesh et al., 2003) as illustrated in Table 2. Selfadministered questionnaire is conducted to collect data, in which respondents answer questions anchored in a 5-points Likert scale, ranging from $1=$ "strongly disagree" to $5=$ "strongly agree". In accordance to eliminate possible ambiguities in the questionnaire, the questionnaires are pretested by one expert in the industry and two volunteer users. This study employs SEM-PLS with the help of Smart PLS 3 software to analyze the data, since the residual is highly non-normal (Hair et al., 2017). Hair et al. (2017) provides guidelines in the data analysis using SEM-PLS.

Table 2: Constructs and Measurement

\begin{tabular}{ll}
\hline \multicolumn{1}{c}{ Construct } & \multicolumn{1}{c}{ Measurement } \\
\hline Religiosity & PE1. The application is useful for me \\
& PE2. Using the application enables me to get food quicker \\
& PE3. Using the app simplifies the process of buying food \\
& PE4. Using the app allows me to reach far away restaurants \\
Effort Expectancy & EE1. My interaction with the app is clear and understandable. \\
& EE2. It would be easy for me to become skillful at using the app \\
& EE3. I would find the app easy to use \\
& EE4. Learning to operate the app is easy for me. \\
& SI1. People who influence my behavior think that I should use the app \\
Social Influence & SI2: People who are important to me think that I should use the app \\
& SI3. I am using the application because my closest people use it \\
& SI4. If I 'don't use the app, people might think 'I'm out of date \\
& FC1. I have the device (smartphone) needed to use the app \\
Facilitating & FC2. I have the knowledge necessary to use the app \\
Condition & FC3. The app is compatible with the device (smartphone) that I use \\
& FC4. I can get help from others if I have difficulty using the app \\
& BI1. I intend to use the app in the next few months \\
BI2. I predict I would use the app in the next few months. \\
BI3. I am planning to use the app in the next few months. \\
BI4. I intend to use the app more often
\end{tabular}

\section{RESULTS}

\subsection{Profile of the Respondents}

Respondents' demographics in Table 3 show the percentages are $27.6 \%$ male and $72.4 \%$ female who participated in this study. In addition, majority of respondents are aged between 26 and 35 years $(52.1 \%)$ and living at Jakarta $(28.3 \%)$. 
Table 3: Profile of the Respondents

\begin{tabular}{clcl}
\hline \hline & Description & Frequencies & Percentage \\
\hline \multirow{2}{*}{ Gender } & Male & 87 & $27.6 \%$ \\
& Female & 228 & $72.4 \%$ \\
& $\leq 18$ & 21 & $6.7 \%$ \\
& $19-25$ & 115 & $36.5 \%$ \\
\multirow{5}{*}{ Domicile } & $26-35$ & 164 & $52.1 \%$ \\
& $\geq 36$ & 15 & $4.8 \%$ \\
& Bandung & 22 & $7 \%$ \\
& Bekasi & 14 & $4.4 \%$ \\
& Bogor & 5 & $1.6 \%$ \\
& Depok & 15 & $4.8 \%$ \\
& Jakarta & 89 & $28.3 \%$ \\
& Semarang & 28 & $8.9 \%$ \\
& Tangerang & 69 & $21.9 \%$ \\
& Yogyakarta & 10 & $3.2 \%$ \\
& Others & 63 & $20 \%$ \\
\hline \hline
\end{tabular}

\subsection{Model Fit Test}

Model fit test reflects the suitability of the model built in the study. A proper model describes the suitability of relationship among variables in the study. SEM-PLS provides the results, and Table 4 shows SRMR and NFI values meet the expected criterion, where SRMR value $<0.08$ and NFI value $>0.9$. As such, it can be concluded that the overall model of this research is fit.

Table 4: Model Fit Summary

\begin{tabular}{ccc}
\hline \hline & Estimated Model & Saturated Model \\
\hline SRMR & 0.040 & 0.040 \\
$d \_U L S$ & 0.195 & 0.195 \\
d_G & 0.221 & 0.221 \\
Chi-square & 307.300 & 307.300 \\
NFI & 0.904 & 0.904 \\
\hline \hline
\end{tabular}

\subsection{Measurement Model (Outer Model Evaluation)}

The outer model is evaluated by examining the individual item reliability, internal consistency, Average Variance Extracted (AVE), and discriminant validity. Individual item reliability is evaluated by reviewing the standardized loading factor, where the score must be higher than 0.5 or ideally more than 0.7 . Results indicate there are several indicators must be excluded from the model as they have a low factor loading value, such as PE4, SI3, SI4, FC4, and BI4. The internal consistency and construct reliability are assessed using Cronbach's Alpha (CA) and Composite Reliability (CR). Their thresholds are the same, where a value higher than 0.7 is acceptable and a value of more than 0.8 is considered very satisfying. Results in Table 5 show that all values were above 0.7 , indicating a high reliability of measures.

In addition, the Average Variance Extracted (AVE) values show that all reflective constructs have AVE values greater than 0.50. Here, the AVE of performance expectancy is 0.542 , effort 
expectancy is 0.660 , social influence is 0.697 , facilitating conditions is 0.676 , and behavioral intention is 0.832 . The results reveal all indicators have met the specified value standards; therefore, the indicators are convergent. Table 5 shows the convergent validity and reliability.

Table 5: Convergent Validity and Reliability

\begin{tabular}{cccccc}
\hline \hline Constructs & Items & Loadings & AVE* & CR* & CA* \\
\hline Performance & PE1 & 0.847 & 0.542 & 0.778 & 0.780 \\
Expectancy & PE2 & 0.644 & & & \\
Effort & PE3 & 0.704 & & & 0.885 \\
Expectancy & EE1 & 0.790 & 0.660 & 0.886 & \\
& EE2 & 0.836 & & & \\
Social & EE3 & 0.783 & & & \\
Influence & EE4 & 0.838 & & & \\
Facilitating & SI1 & 0.943 & 0.697 & 0.818 & \\
Conditions & SI2 & 0.710 & & & \\
& FC1 & 0.819 & 0.676 & 0.862 & \\
Behavioral & FC2 & 0.859 & & & \\
Intentions & FC3 & 0.788 & & & \\
& BI1 & 0.954 & 0.832 & 0.937 & \\
\hline \hline
\end{tabular}

*AVE: Average Variance Extracted; CR: Composite Reliability; CA: Cronbach's Alpha

The discriminant validity test is conducted by comparing the values of cross loading and the values of Square Root of Average Variance Extracted/AVE. Table 6 shows each indicator in its respective construct has a greater cross loading value to its construct. In addition, the value of Square Root of AVE obtained by each construct is greater than the correlation value between constructs with other constructs in the same column. These results satisfy discriminant validity requirements.

Table 6: Discriminant Validity

\begin{tabular}{cccccc}
\hline \hline & PE & EE & SI & FC & BI \\
\hline Performance Expectancy & $\mathbf{0 . 7 3 6}$ & & & & \\
Effort Expectancy & 0.720 & $\mathbf{0 . 8 1 2}$ & & & \\
Social Influence & 0.594 & 0.489 & $\mathbf{0 . 8 3 5}$ & & $\mathbf{0 . 8 2 2}$ \\
Facilitating Conditions & 0.524 & 0.726 & 0.374 & 0.546 & $\mathbf{0 . 9 1 2}$ \\
Behavioral Intention & 0.608 & 0.504 & 0.585 & $\mathbf{0 . 5}$ \\
\hline \hline
\end{tabular}

\subsection{Structural Model (Inner Model Evaluation)}

The assessment of structural model follows these criterions: path coefficient is used to determine the direction of correlation coefficients. Positive correlation coefficient shows there is a positive relationship between constructs and vice-versa. The research model will also be tested by looking at the value of the coefficient of determination $\left(\mathrm{R}^{2}\right)$ as this value explains the variation of dependent variable. The value of $\mathrm{R}^{2}$ is between zero and one. Zero value means independent variables cannot explain the variations of dependent variable. On the contrary, value of one 
indicates the independent variables fully explain the variations of dependent variable. Figure 2 portrays the results of structural model.

Figure 2: Structural Model

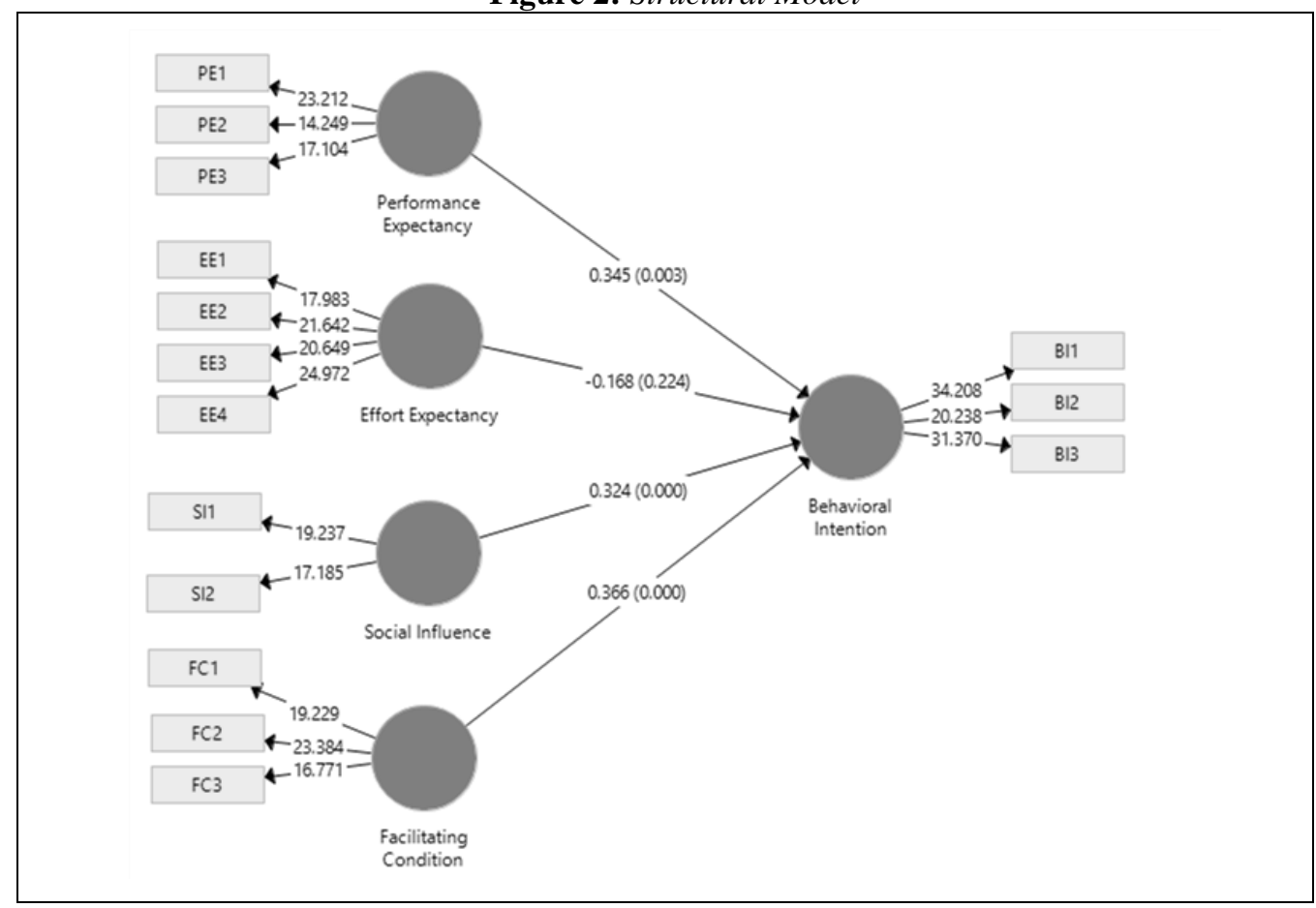

Figure 2 shows a significant influence of performance expectancy on behavioral intention where p-value 0.000 and as such $\mathrm{H} 1$ is supported. Nevertheless, the relationship between effort expectancy and behavioral intention has a p-value of 0.224; hence, H2 is not supported. Social influence significantly influences behavioral intention, where a p-value of $<0.01$; therefore, $\mathrm{H} 3$ is supported. H4 is also supported (p-value < 0.01) since there is a significant influence of facilitating condition on behavioral intention. Facilitating condition delivers the biggest influence as it has the highest standardized loading $(\beta=0.366)$. Finally, the Adjusted R-squared Coefficient is 0.514 , which means $51.4 \%$ variation of behavioral intention is explained by the performance expectancy, effort expectancy, social influence, and facilitating condition. The results of the hypotheses testing are summarized in Table 7 as follows.

Table 7: Summary of Structural Model

\begin{tabular}{cccccc}
\hline \hline Hypothesis & Description & B & T-statistics & P-value & Result \\
\hline H1 & PE $\rightarrow$ BI & 0.345 & 0.260 & 0.003 & Supported \\
H2 & EE $\rightarrow$ BI & -0.168 & 0.004 & 0.224 & Not Supported \\
H3 & SI $\rightarrow$ BI & 0.324 & 0.340 & 0.000 & Supported \\
H4 & FC $\rightarrow$ BI & 0.366 & 0.240 & 0.000 & Supported \\
\hline \hline
\end{tabular}




\section{DISCUSSION}

This research examines the influences of UTAUT elements on behavioral intention to use foodorder feature of ride-hailing applications. Results of the research aim to answer the impacts and to investigate whether the results relate to changes in consumer behavior across Indonesia from offline to online purchasing. Our results are conclusive. Consistent with previous works, performance expectancy, social influence, and facilitating condition positively influence the behavioral intention. Among these variables, facilitating condition delivers the highest impact. Contrary to our hypothesis, effort expectancy does not significantly influence behavioral intention. We highlight below the insights from our study and its contribution over the UTAUT model and shed light on ways to manage multiple features of ride-hailing applications.

\subsection{Theoretical Contributions}

This study extends the general UTAUT concept in predicting technology adoption factors, especially in the context of food-delivery feature in ride-hailing applications. The empirical findings reveal that performance expectancy, social influence, and facilitating condition positively influence behavioral intention to use ride-hailing 'applications' feature for buying food in Indonesia. The results are in line with previous studies, such as Zhou et al. (2020), Rahi and Ghani (2019), Okumus et al. (2018), Isaac et al. (2019), and Yaseen and Qirem (2018). Rahi and Ghani (2019) found a significant effect of performance expectancy on user intention to adopt internet banking, whereas Okumus et al. (2018) found performance expectancy, social influence, facilitating conditions significantly affect 'customers' intention to use smartphone's diet applications when ordering food at restaurants. In a similar vein, Isaac et al. (2019) finds performance expectancy and social influence significantly influence the intention to use the internet within organizations in Yemen. Similarly, Yaseen and Qirem (2018) revealed that social influence is a good predictor to determine user intention to use e-banking services in the Jordanian commercial banks.

Results of this study could explain the changes in consumer behavior in food purchasing across Indonesia. The significant impacts of performance expectancy, social influence, and facilitating conditions may indicate consumers preference to use ride-hailing applications in buying food online, instead of buying offline or cooking food themselves. In this sense, the food-delivery feature in ride-hailing applications is more reliable time after time and as such attracts more sellers to join the ecosystem. This offers varieties of food sellers to consumers which may generate consumers to frequently use the applications. As more and more consumers use the applications, it may induce consumers to socially influence one another in using the applications. The influence may be based on time efficiency, peer-pressures, social trends, superior-pressures, or cost-efficiency. Supported by technological advancement in mobile phones and continuing affordable price of mobile phones, the usage of food-delivery feature may be getting enormous. The combination of these three factors may stimulate change in consumer behavior in Indonesia and this corroborates the shifting trend from offline to online buying in Indonesia.

The justification could be supported by the lens of Transtheoretical Model of Behavioral Change (TTM) approach. Compared to intention-based behavioral models like UTAUT, the TTM describes behavior change as a sequence of stages through which individuals progress toward a desired kind of behavior. The TTM consists of five major stages as follow: (1) pre- 
contemplation, (2) contemplation, (3) preparation, (4) action, and (5) maintenance. Along precontemplation stage, the individual is unaware and does not want to change his/her behavior. Within contemplation step, the individual tries to think about shifting his/her behavior although the cost of change is overestimated, and the person does not change anything. During preparation stage, the individual is starting small actions to make a change within a short period. In the action stage, individuals have changed their behavior as well as modifying necessary behavior and absorbing new behaviors. Finally, individuals proceed to maintenance stage once they succeed in maintaining a change for more than six months and are actively trying to anticipate a regression. During the process, a regression by at least one steps may occur at any stage (Biehl et al., 2019; Friman et al., 2017).

The biggest impact of facilitating condition in this preparation and action level case construct complements the findings on the implementation of UTAUT elements and the possibility of connection with changes in consumer behavior. Former studies found the importance of performance expectancy and social influence in influencing behavioral intention (e.g., Mannan and Haleem, 2017; Talwar et al., 2020). Mannan and Haleem (2017) found performance expectancy is a main factor helping in diffusion process and the success of product innovation adaption that leading to customer satisfaction and customer retention, thereby increasing the chances of changes in consumer behavior. In addition, Soh et al. (2020) explained a model based on the integration of UTAUT and Innovation Resistance Theory (IRT) which revealed that performance expectation and social influence affected online shopping for either younger or older adults. Provided with the availability of options and new products, the tolerance towards decreasing performance is minimal and as such customers exhibit high expectation toward the product since the beginning (Singh \& Thirumoorthi, 2019). In this study, the highest impact of facilitating conditions may signify the ever-increasing consumer demand as a signal of changes in consumer behavior. Our results may indicate the increasing importance of device (smartphone) in the intention to use food-delivery applications. Here, smartphone features maybe viewed as critical prerequisite in conducting many activities, whether it is considered from the included technologies, appearances, functionalities, and so on. Our current study's results extend previous findings by suggesting facilitating condition as the main factor instead of performance expectancy (in the level of preparation and action behavior change). Consumer behavior across Indonesia who is very open to any smartphone models is likely a significant factor as many reports show the high acceptance rate of new smartphone models in Indonesia. In a broader context, the UTAUT model probably is affected by higher acceptance of online consumer behavior and, therefore, it may signal an ever-increasing shift of consumer behavior from offline to online purchasing.

On the other hand, this study shows effort expectancy does not significantly influence intention to use ride-hailing applications' feature for buying food in Indonesia. Whilst former studies on ride-hailing applications corroborate the role of effort expectancy (e.g., Karulkar et al., 2019), the current study finds the insignificant impact of effort expectancy on behavioral intention. This suggests the level of required effort is unlikely a critical factor in 'consumers' decisions on using feature of food order and delivery in ride-hailing applications in Indonesia. In the context of food-delivery feature in a ride-hailing application, this may indicate the easy-to-use of such fooddelivery feature does not demand users to incur additional efforts in operationalizing the feature, and consequently it has insignificant effect on users' behavior. A likely reason for explaining this result is when the user is accustomed to and feels easy to use the digital application, the effect of 
effort expectancy on behavioral intentions decreases (Alharbi et al., 2017; Naranjo-Zolotov et al., 2019). In detail, the $4^{\text {th }}$ item (EE4 = 'learning to operate the app is easy for me') delivers the highest loading of 0.838 . It indicates the food-delivery feature in the ride-hailing applications is easy to learn, and as such consumers likely do not require significant efforts in using the feature.

Based on the TTM approach, effort expectancy is the most important aspect for the initial stage of behavior change (pre-contemplation and contemplation), where the easier the technology, the greater the consumer at the beginning of the stage goes up to the next stage. At the preparation and action levels, consumers have already taken small steps and even tried it, thus they have possessed the experience. In our study, the respondents probably reside at the level of preparation and action stage since the respondent have downloaded ride-hailing apps and utilized the food delivery feature (albeit only once). In such levels, social influence and facilitating conditions, as forms of external factors, are probably the dominant factors to retain consumers to use the applications. Hence, the insignificant effort expectancy then is not enough to generate intention to use the feature. Consequently, effort expectancy is no longer a barrier for users, since users may easily gain help from others (such as their children or younger family members) in using the application.

\subsection{Managerial Implications}

The results of this study are also relevant for practitioners in the online transportation sector or ride-hailing companies. The ride-hailing application industry or online transportation in Indonesia remains growing. Many big competitors intend to enter the Indonesian market and extend the list of ride-hailing companies in Indonesia. In addition, long-established companies such as Gojek and Grab are still trying to expand their markets in Indonesia and its regional surroundings, by continuing to enter new cities and to gain new customers. Lately, Gojek conducts market expansion to other Southeast Asia countries like Singapore, Thailand, and Vietnam, and plans to expand to Malaysia and Philippines in 2020. Therefore, results of this research could be of inputs for practitioners to understand the factors that influence the behavioral intention of consumers who want to adopt a ride-hailing application and its features, especially in food-delivery feature. Based on the research findings, companies are required to continue to upgrade the application and its features since the upgrade may improve the expectancy of platform performance. In addition, companies need to increase their social influence, perhaps by working with influencers, endorsers, and various credible reference groups. The ride-hailing application companies are also probably better to improve various facilities to support consumers in using the application. We also recommend food outlets and restaurant operators to use the food-delivery application due to the change of consumer behavior from offline to online purchasing.

\section{CONCLUSION}

Ride-hailing applications remain significantly growing in Indonesia, including their fooddelivery feature. Despite the significant research attention devoted to this research object, few studies explicitly outline behavioral intention to use the food-delivery feature. In addition, the usage of the feature probably relates to the changes in consumer behavior from offline to online buying. This study tries to identify the critical factors affecting consumers' adoption of ride- 
hailing applications to buy food using Unified Theory of Acceptance and Use of Technology (UTAUT) approach. The findings reveal the model is able to explain $51.4 \%$ of the variance in behavioral intention. Moreover, results show performance expectancy, social influence, and facilitating condition positively influence behavioral intention to use ride-hailing applications for buying food. Notwithstanding, effort expectancy had no significant influence. The findings may relate to the changes in consumer buying behavior, in terms of openness of Indonesian market to accept new models of smartphone (facilitating condition) and the behavior stages. Indonesian consumers likely posit in the preparation and action stages which make effort expectancy irrelevant. We encourage researchers to continue to explore and document how various theories or models affect online consumer behavior.

As of other studies, this current study exhibits limitations which could be a basis for future research. First, this study uses non-probability sampling, and it is recommended that future research should use probability sampling methods, especially stratified sampling covering all regions in a country. Second, the current study only examines the food-delivery feature. Thus, future research could examine other features in ride-hailing application, such as package delivery feature (e.g., GoSend or GrabDelivery) or shopping feature (e.g., GoShop or GrabFresh). Third, our current study only uses UTAUT lens which probably cannot capture many changes in online consumer behavior. Therefore, future researchers can compare various models of technology acceptance theories to see which model best predicts behavioral intention to adopt ride-hailing applications amidst the shift in online consumer behavior.

\section{REFERENCES}

Agarwal, R., \& Karahanna, E. (2000). Time flies when you're having fun: Cognitive absorption and beliefs about information technology usage. MIS Quarterly, 24, 665-694.

Acheampong, R. A., Siiba, A., Okyere, D. K., \& Tuffour, J. P. (2020). Mobility-on-demand: An empirical study of internet-based ride-hailing adoption factors, travel characteristics and mode substitution effects. Transportation Research Part C: Emerging Technologies, 115, 102638. https://doi.org/10.1016/j.trc.2020.102638

Alalwan, A. A. (2020). Mobile food ordering apps: An empirical study of the factors affecting customer e-satisfaction and continued intention to reuse. International Journal of Information Management, 50, 28-44. https://doi.org/10.1016/j.ijinfomgt.2019.04.008

Alharbi, N., Papadaki, M. \& Dowland, P. (2017). The impact of security and its antecedents in behaviour intention of using e-government services. Behaviour \& Information Technology, 36(6), 620-636.

Belanche, D., Flavián, M., \& Pérez-Rueda, A. (2020). Mobile Apps Use and WOM in the Food Delivery Sector: The Role of Planned Behavior, Perceived Security and Customer Lifestyle Compatibility. Sustainability, 12(10), 4275. https://doi.org/10.3390/su12104275

Biehl, A., Ermagun, A., \& Stathopoulos, A. (2019). Utilizing multi-stage behavior change theory to model the process of bike share adoption. Transport Policy, 77, 30-45. https://doi.org/10.1016/j.tranpol.2019.02.001

Cheng, X., Fu, S., \& deVreede, G.-J. (2018). A mixed method investigation of sharing economy driven car-hailing services: Online and offline perspectives. International Journal of Information Management, 41, 57-64. https://doi.org/10.1016/j.ijinfomgt.2018.03.005 
Chua, P. Y., Rezaei, S., \& Gu, M.-L. (2018). Elucidating social networking apps decisions. Nankai Business Review International, 9(2), 118-142. https://doi.org/10.1108/nbri-012017-0003

Contreras, S. D., \& Paz, A. (2018). The effects of ride-hailing companies on the taxicab industry in Las Vegas, Nevada. Transportation Research Part A: Policy and Practice, 115, 63-70. https://doi.org/10.1016/j.tra.2017.11.008

Farooq, M. S., Salam, M., Jaafar, N., Fayolle, A., Ayupp, K., Radovic-Markovic, M., \& Sajid, A. (2017). Acceptance and use of lecture capture system (LCS) in executive business studies. Interactive Technology and Smart Education, 14(4), 329-348. https://doi.org/10.1108/itse06-2016-0015

Fleury, S., Tom, A., Jamet, E., \& Colas-Maheux, E. (2017). What drives corporate carsharing acceptance? A French case study. Transportation Research Part F: Traffic Psychology and Behaviour, 45, 218-227. https://doi.org/10.1016/j.trf.2016.12.004

Friman, M., Huck, J., \& Olsson, L. E. (2017). Transtheoretical Model of Change during Travel Behavior Interventions: An Integrative Review. International Journal of Environmental Researchand Public Health, 14(6), 581. https://doi.org/10.3390/ijerph14060581

Hair, F. J., Hult, G. T. M., Ringle, C., \& Sarstedt, M. (2017). A Primer on Partial Least Squares Structural Equation Modeling (PLS-SEM) ( $2^{\text {nd }}$ ed). Los Angeles: SAGE.

He, F. \& Shen, Z.-J. M. (2015). Modeling taxi services with smartphone-based e-hailing applications. Transportation Research Part C: Emerging Technologies, 58, 93-106.

He, F., Wang, X., Lin, X., \& Tang, X. (2018). Pricing and penalty/compensation strategies of a taxi-hailing platform. Transportation Research Part C: Emerging Technologies, 86, 263279. https://doi.org/10.1016/j.trc.2017.11.003

Indonesian Digital Report. (2020). Digital 2020: Indonesia. https://datareportal.com/reports/digital-2020-indonesia

Howard, R., Restrepo, L., \& Chang, C.-Y. (2017). Addressing individual perceptions: An application of the unified theory of acceptance and use of technology to building information modelling. International Journal of Project Management, 35(2), 107-120. https://doi.org/10.1016/j.ijproman.2016.10.012

Isaac, O., Abdullah, Z., Aldholay, A. H., \& Abdulbaqi Ameen, A. (2019). Antecedents and outcomes of internet usage within organisations in Yemen: An extension of the Unified Theory of Acceptance and Use of Technology (UTAUT) model. Asia Pacific Management Review, 24(4), 335-354. https://doi.org/10.1016/j.apmrv.2018.12.003

Jewer, J. (2018). Patients' intention to use online postings of ED wait times: A modified UTAUT model. International Journal Medicine Informatics, 112, 34-39. https://doi.org/10.1016/j.ijmedinf.2018.01.008

Joia, L. A., \& Altieri, D. (2018). Antecedents of continued use intention of e-hailing apps from the 'passengers' perspective. The Journal of High Technology Management Research, 29(2), 204-215. https://doi.org/10.1016/j.hitech.2018.09.006

Karulkar, Y., Pahuja, J., Uppal, B. S., \& Sayed, S. (2019). Examining UTAUT model to explore consumer adoption in Online Food Delivery (OFD) services. Pramana Research Journal, 9(8), 146-162.

Kurfalı, M., Arifoğlu, A., Tokdemir, G., \& Paçin, Y. (2017). Adoption of e-government services in Turkey. Computers in Human Behavior, 66, 168-178. https://doi.org/10.1016/j.chb.2016.09.041 
Lee, S. W., Sung, H. J., \& Jeon, H. M. (2019). Determinants of Continuous Intention on Food Delivery Apps: Extending UTAUT2 with Information Quality. Sustainability, 11(11), 3141. https://doi.org/10.3390/su11113141

Lu, K., \& Wang, X. (2020). Analysis of Perceived Value and Travelers' Behavioral Intention to Adopt Ride-Hailing Services: Case of Nanjing, China. Journal of Advanced Transportation, 2020, 1-13. https://doi.org/10.1155/2020/4380610

Lwoga, E. T., \& Komba, M. (2015). Antecedents of continued usage intentions of web-based learning management system in Tanzania. Education + Training, 57(7), 738-756. https://doi.org/10.1108/ET-02-2014-0014

Macedo, I. M. (2017). Predicting the acceptance and use of information and communication technology by older adults: An empirical examination of the revised UTAUT2. Computers in Human Behavior, 75, 935-948. https://doi.org/10.1016/j.chb.2017.06.013

Mannan, B., \& Haleem, A. (2017). Understanding major dimensions and determinants that help in diffusion \& adoption of product innovation: using AHP approach. Journal of Global Entrepreneurship Research, 7(12),1-24. https://doi.org/10.1186/s40497-017-0072-4

Mehta, A., Morris, N. P., Swinnerton, B., \& Homer, M. (2019). The Influence of Values on Elearning Adoption. Computers \& Education, $141, \quad 103617$. https://doi.org/10.1016/j.compedu.2019.103617

Morosan, C., \& DeFranco, A. (2016). It's about time: Revisiting UTAUT2 to examine consumers' intentions to use NFC mobile payments in hotels. International Journal of Hospitality Management, 53, 17-29.

Naranjo-Zolotov, M., Oliveira, T., \& Casteleyn, S. (2019). Citizens' intention to use and recommend e-participation. Drawing upon UTAUT and citizen empowerment. Information Technology \& People, 32(2), 364-386. https://doi.org/10.1108/ITP-08-20170257

Nielsen Admosphere. (2019). ABCDE Socio-economic Classification Specification for year 2020. https://www.nielsen-admosphere.eu/wp-content/uploads/2019/12/NielsenAdmosphere-ABCDE-classification-specification 2020.pdf

Okumus, B., Ali, F., Bilgihan, A., \& Ozturk, A. B. (2018). Psychological factors influencing customers' acceptance of smartphone diet apps when ordering food at restaurants. International Journal of Hospitality Management, 72, 67-77. https://doi.org.10.1016/j.ijhm.2018.01.001

Pigatto, G., Machado, J. G. C. F., Negreti, A. S., \& Machado, L. M. (2017). Have you chosen your request? Analysis of online food delivery companies in Brazil. British Food Journal $119(3), 639-657$.

Rahi, S., \& Ghani, M., A. (2019). Investigating the role of UTAUT and e-service quality in internet banking adoption setting. The TQM Journal, 31(3), 491-506. https://doi.org.10.1108/TQM-02-2018-0018

Rana, N. P., Dwivedi, Y. K., Williams, M. D., \& Weerakkody, V. (2016). Adoption of online public grievance redressal system in India: Toward developing a unified view. Computers in Human Behavior, 59, 265-282. https://doi.org/10.1016/j.chb.2016.02.019

Ray, A., Dhir, A., Bala, P. K., \& Kaur, P. (2019). Why do people use food delivery apps (FDA)? A uses and gratification theory perspective. Journal of Retailing and Consumer Services, 51, 221-230. https://doi.org/10.1016/j.jretconser.2019.05.025

Reyes-Mercado, P. (2018). Adoption of fitness wearables: Insights from Partial Least Squares and Qualitative Comparative Analysis. Journal of Systems and Information Technology, 20(1), 103-127. https://doi.org/10.1108/JSIT-04-2017-0025 
Rondan-Cataluña, F. J., Arenas-Gaitán, J., \& Ramírez-Correa, P. E. (2015). A comparison of the different versions of popular technology acceptance models A non-linear perspective. Kybernetes, 44(5), 788-805. https://doi.org/10.1108/K-09-2014-0184

Shiferaw, K. B., \& Mehari, E. A. (2019). Modeling predictors of acceptance and use of electronic medical record system in a resource limited setting: Using modified UTAUT model. Informatics in Medicine Unlocked, 17, 100182. https://doi.org/10.1016/j.imu.2019.100182

Singh, A. K., \& Thirumoorthi, P. (2019). The Impact of Digital Disruption Technologies on Customer Preferences: The Case of Retail Commerce. International Journal of Recent Technology and Engineering (IJRTE), 8(3), 1255-1261. https://doi.org/10.35940/ijrte.C4404.098319

Soh, P. Y., Heng, H. B., Selvachandran, G., Anh, L.Q., Chau, H.T.M., Son, L.H., Abdel-Baset, M., Manogaran, G., \& Varatharajan, R. (2020). Perception, acceptance and willingness of older adults in Malaysia towards online shopping: a study using the UTAUT and IRT models. Journal of Ambient Intelligence and Humanized Computing. https://doi.org/10.1007/s12652-020-01718-4

Suki, N. M., \& Suki, N. M. (2017). Determining students' behavioural intention to use animation and storytelling applying the UTAUT model: The moderating roles of gender and experience level. The International Journal of Management Education, 15(3), 528-538. https://doi.org/10.1016/j.ijme.2017.10.002

Sumak, B., \& Sorgo, A. (2016). The acceptance and use of interactive whiteboards among teachers: Differences in UTAUT determinants between pre- and post-adopters. Computers in Human Behavior, 64, 602-620. https://doi.org/10.1016/j.chb.2016.07.037

Talwar, S., Talwar, M., Kaur, P., \& Dhir, A. (2020). Consumers' Resistance to Digital Innovations: A Systematic Review and Framework Development. Australasian Marketing Journal, 28(4), 286-299. https://doi.org/10.1016/j.ausmj.2020.06.014

Taylor. S., \& Todd, P. A. (1995). Understanding Information Technology Usage: A Test of Competing Model. Information Systems Research, 6(2), 144-176.

Thompson, R. L., Higgins, C. A., \& Howell, J. M. (1991). Personal Computing Toward a Conceptual Model of Utilization. MIS Quarterly, 15(1), 125-143.

Valenta, E. (2019). Food order applications change the behavior of Indonesian consumers. https://beritagar.id/artikel/berita/aplikasi-order-makanan-ubah-perilaku-konsumenindonesia.

Venkatesh, V., Morris, M.G., Davis, G. B., \& Davis, F. D. (2003). User Acceptance of Information Technology: Toward A Unified View. MIS Quarterly, 27(3), 425-478.

Vivoda, J. M., Harmon, A. C., Babulal, G. M., Zikmund-Fisher, B. J. (2018). E-hail (Rideshare) Knowledge, Use, Reliance, and Future Expectations among Older Adults. Transportation Research Part F: Traffic Psychology Behaviour, 55, 426-434. https://doi.org/10.1016/j.trf.2018.03.020

Wang, Y., Wang, S., Wang, J., Wei, J., \& Wang, C. (2020). An empirical study of consumers' intention to use ride-sharing services: using an extended technology acceptance model. Transportation, 47(1), 397-415. https://doi.org/10.1007/s11116-018-9893-4

Wong, K. T., Russo, S., \& McDowall, J. (2013). Understanding early childhood student teachers' acceptance and use of interactive whiteboard. Campus-Wide Information Systems, 30(1), 4-16. https://doi.org/10.1108/10650741311288788

Yaseen, S. G., \& Qirem, I. A. E. (2018). Intention to use e-banking services in the Jordanian commercial banks International Journal of Bank Marketing, 36(3), 557-557. https://doi.org.10.1108/IJBM-05-2017-0082 
Yu, X., Gao, S., Hu, X., \& Hyoshin, P. (2019). A Markov decision process approach to vacant taxi routing with e-hailing. Transportation Research Part B: Methodological, 121, 114134. https://doi.org/10.1016/j.trb.2018.12.013

Zhao, Y., \& Bacao, F. (2020). What factors determining customer continuingly using food delivery apps during 2019 novel coronavirus pandemic period? International Journal Hospital Management, 91, 102683. https://doi.org/10.1016/j.ijhm.2020.102683

Zhou, M., Zhao, L., Kong, N., Campy, K. S., Xu, G., Zhu, G., Cao, X., \& Wang, S. (2020). Understanding consumers' behavior to adopt self-service parcel services for last-mile delivery. Journal of Retailing and Consumer Services, 52, 101911. https://doi.org/10.1016/j.jretconser.2019.101911 